\title{
INFERIORITAS PEREMPUAN DALAM BAHASA IKLAN BANNER SAFETY RIDING
}

\author{
Fedi Bhakti Patria \\ Aktifis Front Mahasiswa Nasional \\ Email: fedibpatria@gmail.com
}

\begin{abstract}
Abstrak
Perempuan masih sering dicitrakan secara peyoratif oleh pemegang otoritas di ruang publik.. Hal ini dapat dilihat dari beberapa elemen yang termaktum dalam citra-citra tersebut, di antaranya dalam teks "Yang Sayang ISTRI/IBU pakai lajur kiri" pada iklan banner safety riding. Penonjolan terma 'ISTRI' dan terma 'IBU' malah memperlihatkan posisi pasif perempuan yang hanya diposisikan sebagai subyek 'yang diam' untuk menunggu pasangannya kembali. Namun dalam hal ini, peraturan tata tertib lalu lintas menjadi representasi dari phallus simbolik. Penelitian ini menggunakan metode kualitatif yang dalam kajian cultural studies dijelaskan oleh Paul Willis sebagai model metodologi refleksif, di mana penekanan terletak pada kesadaran dan kepentingan teoritis, untuk mencapai kedalaman 'realitas'. Hasil penelitian menekankan bahwa citra perempuan tetap disuguhkan sebagai subjek yang pasif dan cenderung patuh terhadap segala aturan-aturan transenden. Maka, tidaklah berlebihan jika pada akhirnya, imaji ini juga merepresentasikan adanya inferioritas pada diri perempuan. Bagaimanapun, hal ini benar-benar mengarahkan, menggiring, dan mendorong para pemirsanya untuk senantiasa memunculkan hasrat-hasrat narsistik pada dirinya. Perempuan dalam citra telah di mitoskan, dan segera ia menjadi bagian dari banalitas dalam ruang-ruang masyarakat.
\end{abstract}

Kata Kunci: bahasa, iklan, safety riding

\begin{abstract}
Women are still often imaged positively by the authorities in the public sphere. This can be seen from some of the elements contained in the images, including in the text "Dear Sweet Wife / Mother wearing the left lane" on banner safety riding ads. The prominence of the term 'WIFE' and the term 'MOM' instead shows the passive position of women who are only positioned as 'silent' subjects to wait for their partner to return. But in this case, the rules of traffic order become the representation of the symbolic phallus. This study uses a qualitative method which in the study of cultural studies is described by Paul Willis as a model of reflexive methodology, where the emphasis lies in theoretical awareness and interest, to reach the depth of 'reality'. The results emphasize that the image of women remains served as a passive subject and tend to be obedient to all
\end{abstract}


transcendent rules. So, it is not excessive if in the end, this image also represents an inferiority in women. However, it really directs, herds, and encourages its viewers to always bring their own narcissistic desires. The woman in the image has been mythical, and soon she becomes part of the banality in the spaces of society.

Keywords: language, advertisement, safety riding

\section{PENDAHULUAN}

Adakah kalian berpikir bahwa hal-hal yang paling banal saat kita beranjak dari rumah dan berjalan berkeliling, bukanlah (satu-satunya lagi) pemandangan indah formasi awan bersanding dengan birunya langit, melainkan, foto-foto model 'cantik', kartun mahsyur, tubuh-tubuh nyaris anorexic, yang terpampang di tiang-tiang listrik, puncak-puncak gedung, maupun serambi-serambi langit dengan jumlah mencapai ratusan. Bukankah menyenangkan juga ketika para model dua dimensi ini, juga mulai memasuki kamar kita, hingga perlahan mulai mengidolakan seonggok tubuh yang kosong - tanpa isi. Adalah iklan, dengan tawaran imaji-imaji ilusif, penuh kilauan warna, dimana ia mampu menggantikan segala sesuatu yang real menjadi item arkais kemudian digantikan dengan yang dimensi non-real.

Iklan benar-benar merupakan wahana 'maha asik' yang menjadi alasan manusia untuk bahagia. Dengannya, subjek manusia disuguhkan impuls-impuls kesenangan eksesif. Iklan, menyajikan segala sesuatunya menjadi terlihat nyata dan tidak pernah mengecewakan pemirsanya. la adalah sahabat baru bagi para pejalan kaki, pengendara sepeda motor, pemain saham, hingga politisi untuk 'mencuci otak'. Sebuah tanda penuh hasrat, yang siap merangkul siapa saja yang menyapanya dalam kehancuran rasio manusia. Layaknya diktum yang dinyatakan oleh Umberto Ecco: "tanda adalah dusta" (dalam Piliang, 2003: 44). Begitu pula 2 | ISSN: 22477-5150 http://journal.unesa.ac.id/index.php/jpi 
iklan, entitasnya selalu palsu. Namun la tidak pernah gagal mewujudkan dirinya sebagai sebuah realitas.

Lantas apa yang menjadikan hubungan antara iklan dan khasanah elementer dari relasi antar manusia menarik untuk dibahas? Mungkin agak sulit untuk menjejalkan pemahaman tersebut kepada beberapa kalangan kelas menengah $n g e h e^{\prime}$ yang tidak terlalu ambil pusing memikirkan bagaimana lautan ideologi berderu melalui banyak iklan yang telah dikonsumsi. 'Enjoy aja!' mungkin adalah jawaban paling hits untuk terus melestarikan ketidaksadarannya. Namun, oleh karena banalitas konsumsi tanda inilah yang sebenarnya menjadi daya tariknya. Sesuatu yang tampak biasa saja, selalu menyimpan ambivalensi di dalamnya.

Atas dasar inilah, sosiologi juga harus ambil peran dalam mengurai ambivalensi tersebut. la (sosiologi) seharusnya tidak lagi hanya berkutat lingkup yang pejal dengan penalaran rasio konservatif. Dimana unsur 'ketidaksadaran' dalam konsumsi iklan juga seyogyanya mendapatkan porsi serupa, daripada harus memunculkan dalih sakralitas 'sosiologi' yang takut apabila realitas bahasa menjadi dominan ketimbang subjek/objek manusia an sich. Hal inilah yang kemudian ditambahkan oleh Stuart Hall, bahwasanya dalam cultural studies sosiologi juga memiliki peranan penting. Sosiologi berguna sebagai perluasan makna budaya dengan semangat 'interdisipliner'. Lebih jauh lagi, harus disadari pula bahwasanya subjek teks merupakan penyatuan dari diskursus ideologi (Hall, et all (ed.), 2011), yang karenanya juga turut andil dalam usaha mengartikulasikan kehidupan masyarakat. Tentu saja, kondisi ini tidak terlepas dari pengaruh ruang-ruang sosial yang ada di perkotaan. Papan iklan berukuran raksasa, banner, mall, dan pusat-pusat perbelanjaan, tentu akan menuntut 
sebuah bangunan diskursif pada masyarakat di dalamnya, sehingga akhirnya harus mempertemukan dua kajian ini dalam satu dimensi yang eklektis.

Pembahasan mengenai iklan dan kaitannya dengan jaring-jaring diskursus maupun pengaruh ideologi, mungkin bisa dilihat dari usaha pembentukan nilainilai universal yang ingin disampaikannya. Entitas iklan, mungkin bisa juga dinyatakan sebagai transformasi dewa Hermes dengan stamina ala Cristiano Ronaldo, mengingat iklan terus berlari dengan kecepatan tinggi mengantarkan pesan tanpa lelah dan senantiasa menawan. Iklan akan selalu menjadi proliferasi metafora-metonimi penandaan, dimana sering kali sebuah peristiwa atau objek dirancang sebagai sebuah analogi dari sebuah produk (Fiske, 2012: 152). Misalnya saja bunga-bunga dan perempuan dalam bath-tub yang menjadi metafora bagi banyak iklan sabun; bunga menjadi metafora dari entitas wewangian, sedangkan perempuan 'ideal' sebagai objek pemasarannya.

Model idiosinkresi yang kemudian banyak mengundang masyarakat untuk berduyun-duyun mengonsumsi tanda, jelas bukan tanpa alasan. Dibalik pesona iklan yang serba hyper, la juga adalah alat produksi hasrat yang memainkan perannya dalam ketidaksadaran manusia. Inilah juga mungkin yang ingin dibangun oleh Jacques Lacan, mengenai 'pembangkitan hasrat' dalam sebuah diskursus untuk menciptakan mispersepsi atas diri. Dimana desire merely leads us to aim at the gap (faille) dan kemudian demonstrated that the One is based only on (tenir de) the essence of the signifier (Lacan, 1998: 5). Maka dapat dikatakan bahwa diskursus menanamkan pengaruhnya kepada sekelompok orang, dengan melingkar disana sebuah lingkaran penanda yang ada pada semua ego ideal, citra tubuh, atau fantasi manusia (Bracher, 2009: 73).

Keterkaitan antara iklan dan hasrat ini, tak pelak juga mengantar tandatanda yang berada dalam iklan menjadi sebuah ruang pertarungan ideologis. la 4 | ISSN: 22477-5150 http://journal.unesa.ac.id/index.php/jpi 
tidak pernah bersifat netral, dan oleh karenanya, tanda dalam iklan selalu beriringan dengan ideologi yang ingin disampaikannya. Dalam pengertian ini, Heck menggambarkan bahwa ideologi senantiasa melampaui dan melibatkan keseluruhan semesta tanda - denotatif dan konotatif (Hall, et all (ed,) 2011: 209). Maka dengan begitu, selalu akan ada yang diarahkan dalam sebuah bangunan hasrat yang diciptakan dari sebuah iklan.

Tentu saja hal ini juga berarti iklan memiliki kemungkinan dalam usaha reproduksi kebudayaan seperti budaya patriarki dalam masyarakat (atau bisa juga melakukan counter). Bagaimanapun sifat 'arbiteristik' tanda dalam iklan, merupakan realitas yang patut dicermati. Pada kasus ini, psikoanalisis jelas memiliki peran penting dalam melihat rasa cemas dan perasaan insecure dari para perempuan saat melihat iklan. Bahkan dalam konferensi Patriarki tahun 1976 yang diadakan di Inggris, memberikan argumen yang mendukung psikoanalisis dalam usaha untuk menguraikan bagaimana perempuan yang terpinggirkan dari budaya laki-laki (Meyers, 2012: 121). Bahkan beberapa aliran feminis postmodern yang muncul, banyak mengadopsi pemikiran psikoanalisis sebagai kerangka analisis pada model budaya kontemporer. Sebut saja Luce Irigaray yang melihat "ketidaksadaran" perempuan dalam budaya laki-laki; juga Kristeva dengan pembacaan serupa dalam mengungkap tiga struktur dimensi narsistik, yaitu primary idealization, abjection, dan melancholy idealization (Sarup, 2003: 207; Beardsworth, 2004: 60).

Terjerembabnya konsep feminin dalam jurang rantai penandaan phallusentric, tidak bisa dilepaskan dari kerangka pemikiran psikoanalisis yang mulai melihat adanya kekurangan (lack) dalam tiap individu saat memasuki fase imajiner (mirror stage) hingga fase simbolik (Bracher, 2009: xxxix). Kemunculan 
hasrat akan kekurangan oleh perempuan yang kemudian menjadikannya sebagai Liyan, dijelaskan oleh Jacques Lacan melalui tiga tahapan Oedipal. Melalui tahapan ini pula, Lacan ingin menunjukkan keterasingan individu dalam ruang simbolik.

Fase pertama yang diajukan oleh Lacan adalah fase pra-Oedipal atau fase real yang melihat sebuah 'kesatuan tubuh' dengan objek disekitarnya. Pada fase kedua, Lacan menjelaskan mengenai fase cermin (imajiner), dimana seorang bayi berpikir bahwa citra akan dirinya, merupakan buah refleksi melalui 'cermin' dari ibunya. Pada fase ini pula, sang anak memandang keterpecahan (fragmenfragmen) atas tubuhnya dan mengalami mispersepsi atas dirinya di dalam cermin sebagai 'Aku'. Hal inilah yang kemudian menjadikan Sang anak sadar akan runtuhnya kesatuan dengan tubuh sang Ibu. Terakhir adalah fase simbolik atau Oedipal, dimana sang anak mulai mengidentifikasikan dirinya, sesuai dengan perannya dalam masyarakat melalui kisaran pemisahan antara 'diri' dan 'liyan' (Bracher, 2009 ; Tong, 2010).

Dengan masuknya perempuan ke dalam fase simbolik, menjadikan perempuan berada dalam ruang ketidaksempurnaan yang terjadi akibat hasrat kekurangannya akan 'penis symbolic'. Berkenaan dengan anatomi inilah, yang kemudian mengakibatkan perempuan tidak dapat menginternalisasi tatanan simbolik secara penuh (Tong, 2010: 289). Sejalan dengan pemikiran Kristeva dalam pembahasannya mengenai perempuan dalam dunia simbol

"Once the symbolic order is entered, the semiotic is repressed, but not thereby superseded... When the symbolic is masculine, the semiotic is akin to, though not identical with, the feminine - it is repressed and marginal. (Milner and Browitt, 2006: 134) 
Pertarungan bahasa dalam dalam dunia simbolik yang cenderung memarjinalisasi perempuan, berkaitan dengan atribut yang disematkan padanya pula. Dalam hal ini, diskursus mengenai nilai 'cantik' menjadi istilah yang bersifat ambivalen. Dengan kerangka psikoanalisis Lacan, Luce Irigaray kemudian mencatat bahwasanya segala sesuatu mengenai citraan perempuan, termasuk hasrat seksualnya didapat dari sudut pandang laki-laki (Tong, 2010: 295).

Bagaimanapun, kajian semiologi dan kaitannya dengan psikoanalisa merupakan hal penting dalam pembahasan mengenai iklan yang disesaki oleh penghasratan. Dalam pembahasannya, Laura Mulvey menggambarkan perempuan berdiri dalam budaya patriarki sebagai penanda bagi diri lain lakilaki, yang diikat oleh tatanan simbolik dimana laki-laki dapat mewujudkan pelbagai fantasi dan obsesinya lewat perintah linguistik (Thornham, 2010: 111). Ini adalah model dari sebuah kebudayaan yang termanifestasikan pula dalam sebuah iklan, dimana terdapat kekuatan phallus symbolic didalamnya, untuk kemudian menciptakan sebuah diskursus yang akan selalu memproliferasi budaya laki-laki. Untuk itu, pembongkaran sistem tanda dalam kacamata psikoanalisis menjadi padanan yang sesuai agar lebih berhati-hati di hadapan hamparan ideologi iklan yang berisi pesan-pesan aforistik, pantun-pantun budaya, maupun imaji-imaji yang tersemat padanya.

\section{METODE}

Penelitian ini menggunakan metode penelitian kualitatif yang lekat dengan teks. Dalam pada itu, teks yang juga bagian dari gejala sosial-budaya dipahami dan ditafsir dalam rangka melihat makna (Rokib, 2013). Dalam kajian cultural 
studies hal ini dijelaskan oleh Paul Willis sebagai model metodologi refleksif, dimana penekanan terletak pada kesadaran dan kepentingan teoritis, untuk mencapai kedalaman 'realitas' (Hall, et all (ed.), 2011: 152). Sedangkan pendekatan yang digunakan adalah Psikoanalsis Jacques Lacan dengan kolaborasi semiologi milik Roland Barthes sebagai alat baca tanda. Unit analisis Lacan menempatkan hasrat sebagai bagian yang penting. Model psikoanalisis Lacan (dalam Bracher, 2009: 30), melihat dua bentuk hasrat secara umum, yaitu hasrat narsistik dan anaklitik. Dimana, hasrat inilah kemudian yang memainkan perannya dalam penggunaan model diskursus.

Data yang digunakan dalam penelitian ini adalah iklan. Iklan ini didapatkan melalui gambar/citra/imaji foto yang diambil di area sekitar Taman Bungkul, Surabaya. Iklan yang didapat melalui foto ini dimaksudkan untuk mempermudah proses analisis intertekstual dengan iklan sejenis, terkait promosi safety riding yang dilakukan oleh Honda, Instansi Kepolisian, dan Jawa Pos.

Analisis data dilakukan dengan menggunakan pendekatan struktural semiologi Roland Barthes. Dimana kemudian la memaparkan beberapa unsur yang kemudian digunakan sebagai alat bedah/baca tanda, yaitu: Pertama, Petanda dan Penanda. Barthes melihat terbentuknya tanda merupakan gabungan dari penanda dan petanda, dimana taraf penanda membentuk taraf ekspresi (E/Expression) dan taraf petanda membentuk taraf isi (C/Contenu) menjadi tanda (R/Relation) (2012: 61). Melalui ini, kemudian bisa diyakini sebagai posisi awal dari signifikansi penanda petanda tingkat pertama atau denotasi; Kedua, Denotasi dan Konotasi. Stuart Hall dengan menggunakan tradisi teori linguistik, melihat pengertian denotasi sebagai makna dari tanda yang bersifat natural, sedangkan konotasi di afilisiaikan dengan ketidaktetapkan dan cenderung memiliki asosiasi pemaknaan lain (During, 2001: 512).

8 | ISSN: 22477-5150 http://journal.unesa.ac.id/index.php/jpi 
Dalam Barthes sendiri, la melihat denotasi sebagai sistem penandaan tingkat pertama, sedangkan sistem penandaan perdua (lebih luas) merupakan taraf konotasi (Barthes, 2012: 132). Lebih lanjut, menurut Hoed (dalam Halim, 2013: 108) konotasi adalah makna baru yang diberikan oleh pemakai tanda, dan jika konotasi menjadi tetap, ia akan menjadi mitos dan bertransformasi menjadi ideology sebagaimana diilustrasikan dalam tabel 1.

\begin{tabular}{|r|r|}
\hline 1. Penanda & 2. Petanda \\
\hline $\begin{array}{r}\text { 3. Tanda } \\
\text { I. PENANDA }\end{array}$ & II. PETANDA \\
\hline \multicolumn{2}{|c|}{ III TANDA } \\
\hline
\end{tabular}

Tabel 1. Penanda dan Petanda

Sumber: Roland Barthes, Membedah Mitos-mitos Budaya Massa (2010: 303)

Berikutnya, analisis dengan psikoanalisa digunakan untuk membuka realitas fantasi dalam iklan banner safety riding, dimana marjinalisasi perempuan dimunculkan dalam tanda-tanda. Penggunaan psikoanalisis dalam membedah sebuah sistem penandaan yang ada pada sebuah citra, juga diperlukan untuk melihat model diskursus dan ideologi yang ditampilkan.

\section{HASIL DAN PEMBAHASAN}

\section{Banner, Periklanan, Hingga Sosialisasi Kebijakan}

Banner sejatinya merupakan perwujudan dari poster iklan yang digunakan untuk mempromosikan hal tertentu. Dalam pembahasan ekonomisnya, Winship 
menjelaskan model periklanan ini sebagai alat penyokong pergerakan komoditas, dari produksi sosial komoditas itu kepada konsumsi individual komoditas tersebut (Hall, et all (ed.), 2011: 354). Oleh karenanya, iklan akan menciptakan sebuah ruang reproduksi pemaknaannya sendiri.

Sejarah periklanan sebenarnya sudah banyak dibahas di zaman sebelum masehi. Seperti sabda-sabda nabi, proklamasi orang Yunai, atau orang-orang Roma yang membawa elang (hawkers). Namun, secara jelas masifnya industri periklanan mulai terjadi antara pertengahan 1850-an dan akhir 1890-an, dimana perekenomian viktorian menjadi saksi dari periode ekspansi besar, keterlebihan industri, dan instabilitas ekonomi yang akhirnya melahirkan peiklanan sebagai produk perekonomian yang dipenuhi uang, sumber daya, dan barang mewah (Meyers, 2012: 3). Tentu model periklanan pada waktu itu tidaklah lebih masal dari hari ini, dimana iklan, poster, baliho, terhampar luas sejauh mata memandang.

Perjalanan iklan sebagai media promosi yang bersifat ekonomis, kemudian juga harus berbagi tempat dengan ranah politik guna mempropagandakan program, sosialisasi, agitasi, hingga melakukan kritik terhadap lawan (politik) nya. Seperti kelompok peretas bertema 'Anonymous' yang banyak menggunakan media gambar guna mengkritisi sistem perekonomian di suatu Negara, melawan peperangan, hingga sosialisasi mengenai kerusakan lingkungan yang terjadi. Dalam beberapa kasus, juga ada kampanye politik yang dilakukan oleh kelompok sayap kiri di Inggris terhadap Greater London Council (Dewan London Raya), hingga mampu menggeser opini publik dan menjadikan pemerintahan partai konservatif kebakaran jenggot (Meyers, 2012: 131).

Kota Surabaya sendiri, cukup gencar dalam upayanya menggunakan iklan sebagai media sosialisasi program kebijakannya dalam bentuk banner dan 10 | ISSN: 22477-5150 http://journal.unesa.ac.id/index.php/jpi 
Fedi Bhakti Patria, Inferioritas Perempuan...(hal. 1-25)

poster. Beberapa titik di Kota tersebut, memiliki persebarannya sendiri. Salah satunya berada di daerah sekitar Taman Bungkul di Jalan Darmo Surabaya. Di daerah tersebut terdapat beberapa banner yang menyuarakan tentang program safety riding dengan mengolaborasikan nilai budaya lokal seperti pantun (parikan) maupun dengan slogan-slogan persuasif. Bahkan sering kali, sosialisasi tersebut mengikutsertakan korporasi yang tentunya memiliki keterkaitan dengan safety riding, seperti beberapa perusahaan otomotif: Honda, Yamaha, Suzuki, dan lain sebagainnya.

\section{Dunia Penanda dan Petanda dalam Banner}

Seperti yang sudah disinggung diatas, penelitian ini mencoba untuk membongkar ideologi yang ada pada citra dalam gambar desain banner sekaligus melihat model diskursus yang dipergunakan. Lacan melihat empat struktur dasar diskursus yang masing-masingnya menghasilkan empat pengaruh sosial: (1) mendidik/mendoktrinasi ; (2) mengatur/memberi ; (3) menghasrati/memprotes ; (4) Menganalisis/ mentransformasikan/merevolusikan (Bracher, 2009: 79). Sehingga dengan ini, akan membantu untuk melihat bagaimana permainan ideologi dimunculkan dalam ruang-ruang diskursus.

\section{Mencandra Teks dalam Banner Safety Riding}

Persona yang awal tampak dalam gambar pada banner adalah sosok kartun yang sekilas mirip perempuan dengan mengendarai sepeda motor dan pesanpesan sosialisasi untuk berjalan di lajur kiri pada bagian atasnya. 


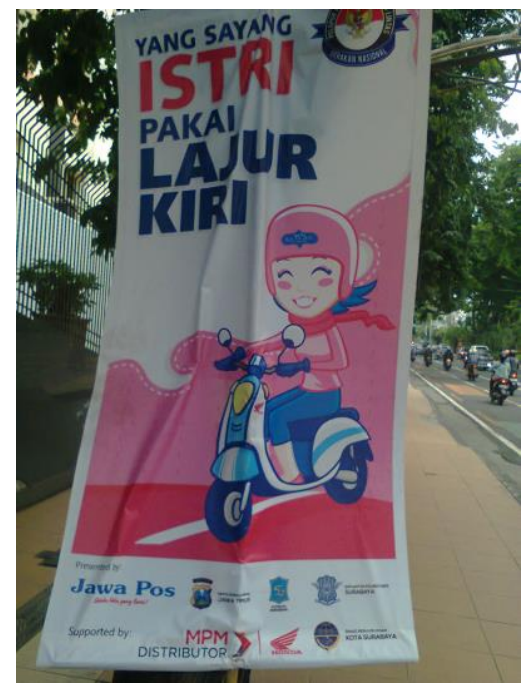

Gambar 1. Banner teks Istri

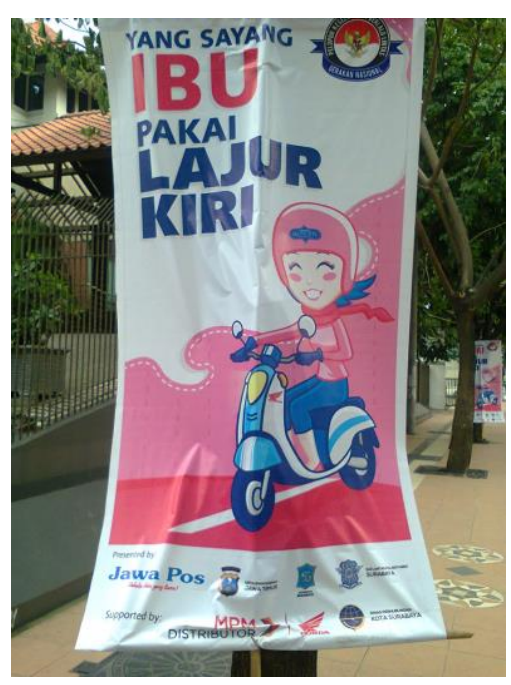

Gambar 2. Banner teks Ibu

Baik pada gambar 1 maupun 2, dapat dilihat bahwa secara bentuk desain dan penempatan teks maupun letak sponsor berada, tidak memiliki perbedaan. Namun, pada teks gambar banner yang ada di pojok kiri atas, memiliki perbedaan dengan penekanan warna merah, yaitu teks "ISTRI" dalam gambar 1, dan teks "IBU" pada gambar 2. Dalam hal ini, terma yang dimunculkan dengan penekanan tertentu, bisa juga diartikan sebagai tanda 'kepada siapa tanda ini ditujukan'.

Dalam pandangan semiotika Levi's Strauss, la melihat dimensi paradigmatik bahasa dalam sebuah struktur yang la sebut oposisi biner, dimana pemahaman akan realitas akan didapat dari pembedaan tersebut (Fiske, 2012: 191). Lebih lanjut, hal ini digunakan sebagai model pemahaman: realitas A tidak akan berdiri sendiri tanpa hubungan terstrukturnya dengan realitas B. Kemudian, pemahaman ini juga bisa diaplikasikan terhadap teks "IBU" maupun "ISTRI" pada 
gambar diatas, dimana oposisi biner yang menghubungkan keduanya adalah "IBU" > "BAPAK" dan "ISTRI" > "SUAMI", atau dalam pengertian yang lebih luas: "Entitas Perempuan" dengan "Entitas Laki-laki". Pemaknaan secara denotatif pun mungkin akan mengamini perihal diatas. Dimana pesan penanda "IBU" dan "ISTRI" memiliki padanan petandaan dengan entitas perempuan.

Kondisi ini, sekaligus menjadikan perempuan sebagai 'objek yang diam'. Dengan pernyataan "Yang sayang" diatas terma "IBU" maupun "ISTRI", bisa juga merujuk pada pengartian seseorang yang 'disayangi'. Barthes melihat hal ini sebagai "the absent one", dimana la banyak berbicara posisi perempuan yang 'didiamkan' karena dicintai. Menurutnya "historically, the discourse of absence is carried on by the Woman: Woman is sedentary, Man hunts, journey; Woman is faithful (she waits), man is fickle (he sails away, he cruises) (Barthes, 2001: 1314, penekanan oleh penulis). Maka, kerangka diskursus yang ingin dibangun adalah konsep perempuan diam dan taat aturan lalu lintas. Sedangkan entitas laki-laki, digambarkan sebagai sosok liar dan selalu melanggar aturan.

\section{Citra, Warna, dan Objek Androgini}

Beranjak menuju model gambar yang terdapat pada iklan banner. Dapat dilihat dalam gambar, adanya sosok yang mirip perempuan mengenakan helm dan mengendarai sepeda motor, dengan senyuman tampak di wajahnya. Tipikal warna yang ada disekitarnya adalah merah jambu dengan aksen biru muda di beberapa titik pada tubuh dan sepeda motor yang digunakan.

Dalam tradisi semiotika struktural, warna juga menjadi hal penting dalam sebuah relasi tanda. Saussure melihat bahwa pemaknaan hal yang diproduksi dari relasi antara petanda dan penanda (Storey, 2009: 111). Sebagai contoh, 
lampu lalu lintas yang beroperasi dengan tiga sistem warna: merah berarti behenti, kuning berarti bersiap-siap, dan hijau yang berarti jalan. Pada kasus ini, hubungan penanda dan petanda akan selalu bersifat arbiter, sehingga tidak bisa kita mengartikan warna merah pada lampu lalu lintas dengan makna lain diluar sistem penandaan yang berlaku secara universal.

Kembali pada pembahasan warna yang terdapat pada gambar iklan banner diatas, maka jika boleh menerjemahkan warna dan sosok androgini yang menyerupai perempuan tersebut, maka ada kemungkinan sosok yang tergambar pada banner tersebut adalah perempuan. Hal ini mungkin bisa dinilai dari komposisi warna pastel pada gambar: merah jambu dan biru muda, maka secara denotatif, asosiasi yang paling mendekati sosok yang menaiki sepeda motor tersebut adalah perempuan.

Bukan bermaksud secara telak menyatakan bahwa sosok penuh senyum dalam gambar adalah perempuan. Namun kita coba menyepakati bahwa analisa secara struktural mempertemukan penanda manusia berambut separuh panjang dengan petanda berupa warna merah jambu, bulu mata, lipstick, sepeda motor matic, dan 'tubuh ideal' bertransformasi menjadi sebuah tanda baru, entitas perempuan. Lalu dengan performa demikian, maka berjalan pula proses konotatif dalam sebuah citra.

Dalam model sistem penandaan tingkat dua milik Barthes, la mengenalkan konsep mitos. Dimana mitos diartikan sebagai kelaziman dalam kebudayaan (Fiske, 2012: 144). Jika pada umumnya, perempuan hanya digambarkan sebagai subjek pasif yang hanya menyerahkan dirinya sebagai sarana prokreasi dan identik dengan pekerjaan domestik. Melalui gambar ini, subjek perempuan dalam gambar dipertontonkan sebagai perempuan yang menempatkan dirinya diluar lingkungan rumah. Mitos dalam gambar ini kemudian bergerak maju 14 | ISSN: 22477-5150 http://journal.unesa.ac.id/index.php/jpi 
kearah bagaimana konstruksi tubuh a la perempuan modern bersolek, yaitu dengan mengenakan lipstick dan bulu mata lentik, ditambah model asesoris fashion berupa syal.

Perlu diingat, bahwasanya mitos dalam pengertian ini bertugas sebagai aparatur (kalau boleh saya menyebutnya) yang menetralisisr sejarah. Jadi dengan demikian, perempuan dalam gambar ini merepresentasikan 'anak zamannya'. Hal ini, tentu tidak bisa juga hanya dibaca secara parsial antara mode dan maksud yang ada pada gambar. Karena mitos jika sudah memantapkan dirinya, juga akan bermetamorfosis lagi menjadi apa yang kita sebut sebagai ideologi.

Bagaimanapun akan terlihat 'aneh' jika kita memerhatikan keadaan geografis secara umum di Indonesia. Iklim Negara Indonesia adalah tropis, namun penggunaan syal pada gambar perempuan dalam iklan banner cenderung mengarah pada kondisi iklim di dataran tinggi atau mungkin wilayah eropa? Maka perlu pula dilakukan pelacakan atas trace atau jejak-jejak dari distorsi petanda dalam gambar tersebut.

Mirip dengan Barthes dalam Mitologinya (2010: 64-68) yang menggambarkan pengonsumsi anggur dan representasi masing-masing kelasnya. Penggunaan syal, kosmetik, dan alat-alat lainnya mengaburkan realitas asalinya, sehingga menggiring pemirsanya kepada suatu pembenaran dalam ruang dimensi politis atau sosial mereka. Dengan ini, dapat dinyatakan pula adanya ideologi kelas atas yang menyusup. Sehingga gesture dalam gambar dikemas sedemikian rupa hingga menjadikannya nampak alami.

Selain menampilkan model citra perempuan yang berada di ruang publik sekaligus berbusana modern khas kelas atas. Pada gambar tersebut juga memperlihatkan adanya garis putus-putus menyerupai markah jalan. Kemudian 
jika kita menggunakan perspektif dari gambar tersebut, perempuan berada di lajur kiri dan ada di dalam markah jalan. Hal lain yang bisa diperhatikan dari adanya garis markah tersebut, adalah 'seorang pengendara sepeda motor matic perempuan yang taat berlalu lintas'. Dimana, dari objek dalam gambar berupa garis markah, terdapat beberapa makna konotatif yang terlampir dalam 'markah' tersebut.

Dalam citra markah yang ada pada gambar iklan banner, tentu selain memiliki makna dari sebuah citra ideal akan ketertiban di jalan raya, terdapat makna lain lagi yang hendak disampaikan. Beberapa spekulasi yang kemudian muncul secara bersamaan dengan momentum citra kepatuhan perempuan dalam berlalu lintas adalah perempuan yang setia, perempuan yang nurut, juga perempuan yang bebas dalam batasan-batasan tertentu.

Citra perempuan tetap disuguhkan sebagai subjek yang pasif dan cenderung patuh terhadap segala aturan-aturan transenden. Maka, tidaklah berlebihan jika pada akhirnya, imaji ini juga merepresentasikan adanya inferioritas pada diri perempuan. Bagaimanapun, hal ini benar-benar mengarahkan, menggiring, dan mendorong para pemirsanya untuk senantiasa memunculkan hasrat-hasrat narsistik pada dirinya. Perempuan dalam citra telah di mitoskan, dan segera la menjadi bagian dari banalitas dalam ruang-ruang masyarakat.

Pergumulan hamparan citra dalam banner safety riding dengan kemunculan hasrat didalamnya, mungkin akan bisa semakin tampak melalui pisau milik psikonalisis. Harus disadari memang, mekanisme bagaimana tanda bekerja, baik itu dalam sebuah citraan foto hingga video, akan banyak bermain dalam ruang ketidaksadaran milik subjek. 


\section{Fantasi dalam Gambar: Kegegaran Dua Subjek dalam Ruang Diskursus}

Melalui pembacaan semiologi ini, kemudian psikoanalisis masuk sebagai jembatan dimana ketidaksadaran subjek menjadi sangat dimungkinkan dalam usaha pengonsumsian terhadap iklan. Lacan melihat model yang ditawarkan dalam iklan ini sebagai perwujudan dari diskursus yang membelah sang subjek, sehingga la teralienasi dan akan dihasrati oleh Liyan, karena bagi Lacan hasrat yang otentik tidaklah ada. Man's desire is alienated in other's desire (Lacan, 2006: 525). Dalam hal ini fantasi subjek dipermainkan sehingga mereka tidak akan pernah berhenti berhasrat.

Keterhubungan mengenai advertising dengan psikoanalisis memang banyak menjadi sorotan. Arthur Asa Berger misalnya, la mencermati adanya penggunaan unsur narsistik dalam iklan kosmetik L'Oréal. Dengan pernyataan "Because you're worth it", yang menurutnya L'Oréal membangun ide kekaguman akan diri, sekaligus memberikan ancaman untuk 'ditarik keluar' jika tidak turut berpartisipasi mengonsumsi produk tersebut (Berger, 2010: 101)

Analisis yang dilakukan oleh psikoanalisis, selain melihat bagaimana kondisi narsistik dialami oleh subjek, juga memerhatikan mengenai adanya simtom. Maka dalam melihat diskursus pada iklan, penting kiranya untuk mengangkat posisi simtom a la Lacan yang mengambil bentuk berupa diskursus atau wacana. Dimana dalam hal ini terdapat empat faktor dasar yang mendiami sebuah diskursus, yaitu: $\mathrm{S}_{1}$ (penanda utama/nilai ideal), $\mathrm{S}_{2}$ (sistem pengetahuan/gagasan universal), a (hasrat berlebih/object a), dan \$ (subjek gegar) (Lacan, 1998: 17, penambahan dengan huruf tebal oleh penulis).

Berjalannya sebuah diskursus ini, menjadikan para pemirsanya 'terhasrati'. Objek 'Liyan' yang termanifestasikan melalui mekanisme simbolik, baik itu 
bahasa, citra, teks, hingga dalam kasus ini adalah iklan, akan selalu menghasrati subjek dan memunculkan gejolak narsistik. Dalam hal ini, gradasi warna maupun apa yang tampak dalam gambar pada iklan banner safety riding memiliki tendensi dalam upaya mengarahkan pemirsanya.

Dengan melihat struktur diskursus yang dihamparkan dalam gambar yang sudah di analisis sebelumnya menggunakan kacamata semiologi, maka dapat dilampirkan sebagaimana gambar 3 .

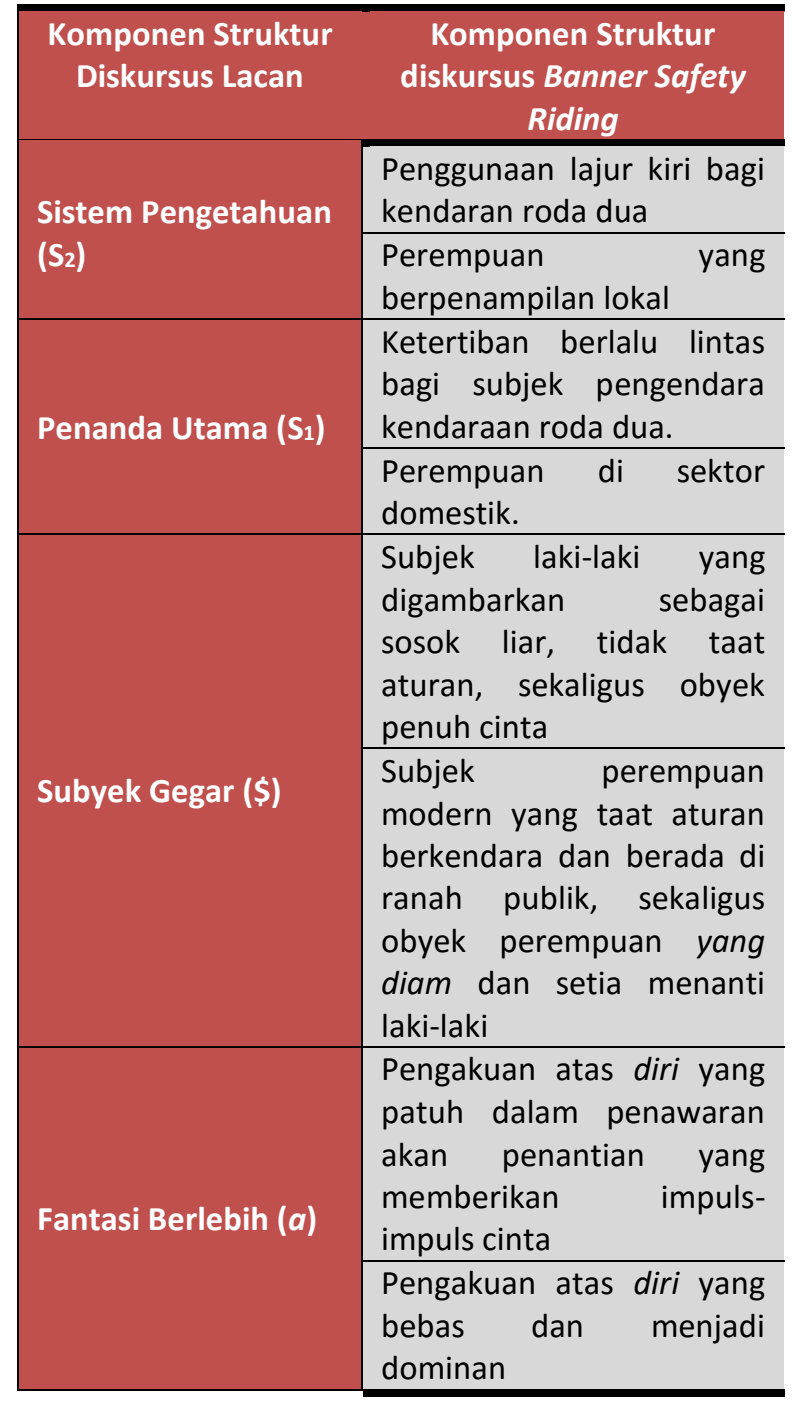

18 | ISSN: 22477-5150 http://journal.unesa.ac.id/index.php/jpi 


\section{Gambar 3. Komponen Struktur Diskursus}

Berdasarkan struktur diskursus diatas, dapat dilihat bahwa terdapat dua perwujudan subjek gegar (\$), yang mana dipaparkan pada analisis semiologi sebelumnya jika pesan citra dalam banner safety riding ini memiliki dua tujuan penyampaian. Pertama adalah subyek laki-laki dengan keliarannya, sehingga dalam poster tersebut menawarkan impuls-impuls cinta melalui logika binernya: perempuan (istri/ibu). Kedua, subyek gegar diarahkan pada model perempuan yang berpakaian modern yang sekaligus berperan sebagai objek yang diam dan patuh.

Kemudian, Sistem pengetahuan $\left(\mathrm{S}_{2}\right)$ memainkan perannya sebagai komponen agen yang mengasosiasikan diri dengan keberadaan fantasi/kesenangan berlebih (a). Setelah itu, kedua subyek gegar (\$), dalam hal ini membenarkan kondisi ketertekanan yang terjadi pada mereka, untuk secara terus menerus dihasrati lalu mengantarkannya kepada sebuah entitas mitos atau nilai ideal

Dalam proporsi yang demikian, kemudian coba digambarkan Lacan (1998: 16) dalam model diskursus universitas sebagai berikut:

$$
\frac{S_{2}}{S_{1}}<>\frac{a}{\$}
$$

Dari sini, subyek laki-laki (\$) dalam diskursus memosisikan dirinya untuk senantiasa berada dalam bayang-bayang object $a$. Subyek ini, bertugas untuk memproduksi/mereproduksi sistem pengetahuan yang dipancing melalui impulsimpuls cinta yang eksesif. Teks "Yang sayang ISTRI/IBU pakai lajur kiri" memiliki objek sublim yang menjanjikan suatu pertemuan ontologis terhadap entitas perempuan dan laki-laki sebagai resipennya. Dalam tragedi dramatis ini, epos 
oedipal kembali dimunculkan. Dimana pemirsa disuguhkan dalam kisah percintaan dengan Ibunya sendiri. Entitas perempuan mungkin untuk lebih tepatnya.

Kemenyatuan antara subyek laki-laki 'liar' dengan 'ibu simbolik' ini, kemudian beralih pada tatanan imajiner yang mengakibatkan adanya kesalahpahaman dalam mengenali diri (misperception). Kesalahpahaman akan diri ini muncul pertama-tama melalui kepercayaan atas keberadaannya (exist), yang juga memunculkan kesadaran akan keterpisahan diri dengan entitas diluar tubuhnya. Pada akhirnya, la pasti akan melihat kemunculan nom-du-père (ayah simbolik) yang mengancam subyek laki-laki dengan kastrasi (Bracher, 2009: xxxix).

Ayah simbolik ini merupakan metafora bagi dunia simbolik, dimana nilai, norma, hukum, bahasa, dan kebudayaan beroperasi sebagai Liyan. Melalui ini, subyek gegar dihadapkan dengan penanda utama/master signifier $\left(\mathrm{S}_{1}\right)$ yang menciptakan truth atau nilai-nilai yang dianggap ideal. Dengan medium bujuk rayu ini, subyek laki-laki diharapkan akan mengalami ketertundukkan dan memenuhi dirinya dengan semesta hasrat yang mengantarkan kepada kondisi nyaman yang bersifat kontinu, jika masyarakat mematuhi aturan-aturan tersebut.

Kondisi yang terjadi pada subyek gegar laki-laki, berbeda halnya dengan yang terjadi pada subyek gegar perempuan. Dalam pembahasan pada sub bab sebelumnya, dijelaskan mengenai paradoks posisi citra perempuan dalam gambar. Dimana pada satu sisi, la merupakan representasi dari mode budaya modern dengan busana dan keberadaannya di ruang publik. Namun di sisi lain, la juga mewakili kondisi perempuan yang 'diam' sebagaimana terlampir dalam teks "Yang sayang ISTRI/IBU pakai lajur kiri", perempuan disini diposisikan sebagai 20 | ISSN: 22477-5150 http://journal.unesa.ac.id/index.php/jpi 
Fedi Bhakti Patria, Inferioritas Perempuan...(hal. 1-25)

subyek diam yang menunggu. Lebih lanjut, pembongkaran makna markah jalan yang diartikan sebagai batasan budaya milik perempuan dan tidak boleh dilanggar, sehingga inferioritas terhadap pengakuan diri perempuan pada akhirnya juga harus berakhir dengan kastrasi.

Citra perempuan dalam kasus ini menempatkan dirinya sebagai subyek yang histeris dalam sistem diskursus:

$$
\frac{\$}{a}<>\frac{\$_{1}}{S_{2}}
$$

Posisi diskursus yang histeris menempatkan subyek sebagai agen yang menyerahkan diri kepada penanda utama. Subjek gegar, dalam diskursus ini melakukan perlawanan terhadap sistem pengetahuan $\left(S_{2}\right)$ dan penanda utama $\left(\mathrm{S}_{1}\right)$. Dengan demikian, subyek gegar merupakan manifestasi dari sebuah alienasi yang ditekan dalam mekanisme kebudayaan untuk kemudian tampil sebagai dominan dalam diskursus yang histeris.

Subjek gegar, yang diwakili oleh citra perempuan melakukan penolakan terhadap keberadaan penandaan utama yang hanya berkutat pada ranah domestik $\left(\mathrm{S}_{1}\right)$ sekaligus terhadap model perempuan dengan gagasan-gagasan fashion lokal/konvensional. Fashion lokal/konvensional yang dimaksudkan disini adalah mode khas yang disesuaikan dengan kondisi geografis, iklim, dan budaya yang berjalan di wilayah tertentu.

Penolakkan ini, sebenarnya merupakan momen yang penting dalam usaha interpelasi terhadap adanya sebuah revolusi. Namun, yang perlu diperhatikan juga adalah kondisi histeris yang dialami oleh subjek gegar. Lalu apa yang menjadikannya demikian? Tentu hal itu ada pada pencarian akan kepuasan, 
penghilangan rasa cemas, dan lain sebagainya akibat dari pengucilan subyek oleh penanda utama dan sistem pengetahuan.

lalah object $a$, yang akan selalu menjadi lubang hasrat tanpa dasar. Diskursus yang histeris adalah diskursus yang memiliki optimisme nihil, karena pada dasarnya object $a$ tidak pernah hadir. Lacan kemudian membahasakan hal ini sebagai Lamella, seperti yang dikatakannya "It is the libido...that is to say, immortal life, or irrepressible life, life that has need of no organ, simpli-fied, indestructible life." (Lacan, 1981: 198).

Kegelisahan yang dialami oleh subjek gegar yang berdiri sebagai agen, alihalih menghapuskan objek yang menyebabkan kemunculan hasrat tersebut, ternyata semakin menghasilkan limpahan hasrat tanpa henti. Lamella menciptakan wadah baru bagi object $a$ untuk kemudian memuculkan diri sebagai objek sublim yang selalu diidam-idamkan.

Berangkat dari analisis sebelumnya, di mana lema "IBU/ISTRI" mewakili perempuan yang diam di dalam teks keseluruhannya. Menunjukkan ada pertentangan dengan apa yang menghasrati subyek perempuan yang terbelah atau gegar. Metonimi kelas atas dengan busana modern, memainkan peran di sektor publik, hingga penggunaan sepeda motor matic, merupakan keterpecahan dari bagaimana hasrat-hasrat dimunculkan.

Citra dalam gambar banner tersebut tidaklah mendapat apa-apa. la sekali lagi menjadi subjek histeris yang harus terbelenggu dalam ruang-ruang simbolik. Penggambaran mengenai ketaatannya dalam berkendara, juga sekaligus menggambarkan berlari kembalinya la dalam kuasa phallus. 


\section{SIMPULAN}

Pemaparan konkrit mengenai apa yang ingin disampaikan dalam citra dalam banner safety riding ialah posisi perempuan yang masih berada dalam keinferioritas-an. Hal ini dapat dilihat dari beberapa elemen yang termaktum dalam citra-citra tersebut, diantaranya dalam teks "Yang Sayang ISTRI/IBU pakai lajur kiri". Di mana, penonjolan terma 'ISTRI' dan terma 'IBU' malah memperlihatkan posisi pasif perempuan yang hanya diposisikan sebagai subyek 'yang diam' untuk menunggu pasangannya kembali.

Di sisi lain, posisi laki-laki sebagai yang dialamatkan pada pesan tersebut, sebenarnya secara tidak langsung juga menempatkan dirinya sebagai entitas superior. Keliaran, perilaku tidak patuh, hingga bergerak secara pro-aktif, merupakan diskursus yang ingin dibangun jika berkaca pada citra perempuan dalam banner sebagai subyek yang taat hukum. Hal ini kemudian juga menjadi salah satu faktor yang melahirkan kembali ideologi patriarki dalam masyarakat. Meskipun dalam hal lain, banner safety riding ini juga mempermainkan impulsimpuls kecintaan akan dunia real terhadap kesatuan tubuh subjek laki-laki, dengan sosok ibu simbolik.

Penggambaran lain mengenai citra tubuh perempuan dalam banner tersebut adalah penggunaan fashion modern, dengan mengendarai motor matic. Penegasan yang sekilas terlihat sebagai perwujudan dari masuknya perempuan ke ranah publik, jika diperhatikan lebih jeli, malah menampilkan sosok citra perempuan yang lagi-lagi menjadi pribadi yang diam dan taat. Namun dalam hal ini, peraturan tata tertib lalu lintas menjadi representasi dari phallus simbolik. Hal ini jelas berbeda dengan proporsi yang dimiliki oleh laki-laki simbolik, dimana la tetap berperan sebagai aktor protagonis yang lebih aktif dan berani melawan 
arus, ketimbang perempuan yang diam menunggu dan taat terhadap dunia simbolik.

\section{DAFTAR PUSTAKA}

Barthes, Roland. 2001. A Lover's Discourse. Cet. XXII. (terj. Richard Howard). New York: Hill and Wang 2010. Membedah Mitos-Mitos Budaya Massa. Cet. III. (terj. Ikramullah Mahyuddin). Yogyakarta: Jalasutra

2012. Elemen-Elemen Semiologi. Cet. I. (terj. M. Ardiansyah). Jogjakarta: IRCiSoD

Beardsworth, Sara. 2004. Julia Kristeva and Modernity. Cet. I. New York: State University of New York Press

Berger, Arthur Asa. 2010. The Object of Affection, Semiotic and Consumer Culture. Cet. 1. New York: Palgrave Macmillan

Bracher, Mark. 2009. Jacques Lacan, Diskursus, dan Perubahan Sosial: Pengantar Kritik-Budaya Psikoanalisis. Cet. II. (terj. Gunawan Admiranto). Yogyakarta: Jalasutra

During, Simon. 1999. The Cultural Studies Reader. Cet. II. New York: Routledge Fiske, John. 2012. Pengantar IImu Komunikasi. Cet. I. (terj. Hapsari Dwiningtyas). Jakarta: RajaGafindo

Halim, Syaiful. 2013. Postkomodifikasi Media. Cet. I. Yogyakarta: Jalasutra

Hall, Stuart, et al (ed.). 2011. Budaya, Media, Bahasa. Cet. I (terj. Saleh Rahmana). Yogyakarta: Jalasutra

Lacan, Jacques. 1981. The Seminar of Jacques Lacan, Book XI: The Four Foundamental Concepts of Psychoanalysis. Cet. II (terj. Alan Sheridan; ed. Jacques-Alain Milner) New York: W. W. Norton \& Company

24 | ISSN: 22477-5150 http://journal.unesa.ac.id/index.php/jpi 
Fedi Bhakti Patria, Inferioritas Perempuan...(hal. 1-25)

1998. The Seminar of Jacques Lacan, Book XX: Encore 1972-1973.

On Feminine Sexuality The Limits of Love and Knowledge. Cet. I. (terj. B.Fink). NY, London: W.W. Norton and Company, 1998)

2006. Écrits. Cet. II (terj. Bruce Fink). New York: W.W. Norton \& Company, Inc.

Milner, Andrew and Jeffrey Brownitt. 2006. Contemporary Cultural Theory, An Introduction. New York: Routledge.

Myers, Kathy. 2012. Membongkar Sensasi dan Godaan Iklan. Cet. I. (terj. Asma Bey Mahyuddin). Yogyakarta: Jalasutra

Piliang, Yasraf Amir. 2003. Hipersemiotika, Tafsir Cultural Studies Atas Matinya Makna. Cet. I Bandung: Jalasutra.

Rokib, Mohammad. 2013. Teologi Bencana: Studi Santri Tanggap Bencana. Yogyakarta: Buku Pintal.

Sarup, Madan. 2003. Posstrukturalisme dan Posmodernisme, Sebuah Pengantar Kritis. Cet. I (terj. Medhy Aginta Hidayat). Yogyakarta: Jendela

Storey, John. 2009. Cultural Theory and Popular Culture, An Introduction. Cet. V. London: Pearson

Thornham, Sue. 2010. Teori Feminis dan Cultural Studies, Tentang Relasi yang Belum Terselesaikan. (Terj. Asma Bey). Yogyakarta: Jalasutra.

Tong, Rosemarie Putnam. 2010. Feminist Thought : Pengantar Paling Komprehensif kepada Aliran Utama Pemikiran Feminis. (Terj. Aquarini Priyatna Prabasmoro). Yogyakarta : Jalasutra. 